\title{
Front Matter: Volume 9561
}

, "Front Matter: Volume 9561," Proc. SPIE 9561, Thin Films for Solar and Energy Technology VII, 956101 (5 September 2015); doi: 10.1117/12.2218488

SPIE Event: SPIE Optics + Photonics for Sustainable Energy, 2015, San Diego, California, United States 


\title{
PROCEEDINGS OF SPIE
}

\section{Thin Films for Solar and Energy Technology VII}

\author{
Louay A. Eldada \\ Michael J. Heben \\ Editors
}

9-10 August 2015

San Diego, California, United States

Sponsored and Published by

SPIE

\section{Volume 9561}


The papers in this volume were part of the technical conference cited on the cover and title page. Papers were selected and subject to review by the editors and conference program committee. Some conference presentations may not be available for publication. Additional papers and presentation recordings may be available online in the SPIE Digital Library at SPIEDigitallibrary.org.

The papers reflect the work and thoughts of the authors and are published herein as submitted. The publisher is not responsible for the validity of the information or for any outcomes resulting from reliance thereon.

Please use the following format to cite material from these proceedings:

Author(s), "Title of Paper," in Thin Films for Solar and Energy Technology VII, edited by Louay A. Eldada, Michael J. Heben, Proceedings of SPIE Vol. 9561 (SPIE, Bellingham, WA, 2015) Sixdigit Article CID Number.

ISSN: 0277-786X

ISSN: 1996-756X (electronic)

ISBN: 9781628417272

Published by

SPIE

P.O. Box 10, Bellingham, Washington $98227-0010$ USA

Telephone +1 3606763290 (Pacific Time) · Fax +1 3606471445

SPIE.org

Copyright (C) 2015, Society of Photo-Optical Instrumentation Engineers.

Copying of material in this book for internal or personal use, or for the internal or personal use of specific clients, beyond the fair use provisions granted by the U.S. Copyright Law is authorized by SPIE subject to payment of copying fees. The Transactional Reporting Service base fee for this volume is $\$ 18.00$ per article (or portion thereof), which should be paid directly to the Copyright Clearance Center (CCC), 222 Rosewood Drive, Danvers, MA 01923. Payment may also be made electronically through CCC Online at copyright.com. Other copying for republication, resale, advertising or promotion, or any form of systematic or multiple reproduction of any material in this book is prohibited except with permission in writing from the publisher. The CCC fee code is $0277-786 \mathrm{X} / 15 / \$ 18.00$.

Printed in the United States of America.

Publication of record for individual papers is online in the SPIE Digital Library.

\section{SPIE. DIGITAL \\ SPIEDigitallibrary.org}

Paper Numbering: Proceedings of SPIE follow an e-First publication model. A unique citation identifier (CID) number is assigned to each article at the time of publication. Utilization of CIDs allows articles to be fully citable as soon as they are published online, and connects the same identifier to all online and print versions of the publication. SPIE uses a six-digit CID article numbering system structured as follows:

- The first four digits correspond to the SPIE volume number.

- The last two digits indicate publication order within the volume using a Base 36 numbering

system employing both numerals and letters. These two-number sets start with 00, 01, 02, 03, 04 05, 06, 07, 08, 09, OA, OB ... 0Z, followed by 10-1Z, 20-2Z, etc. The CID Number appears on each page of the manuscript. 


\title{
Contents
}

\author{
$\checkmark \quad$ Authors \\ vii Conference Committee \\ ix Photochemical upconversion of light for renewable energy and more (Plenary Paper) \\ [9562-202]
}

\section{SESSION 1 SIMULATION, MODELLING, TESTING, AND METROLOGY}

956102 Combined optical-electrical finite-element simulations of thin-film solar cells: preliminary results $[9561-1]$

956103 Theoretical limits of the multistacked 1D and 2D microstructured inorganic solar cells [9561-2]

\section{SESSION 2 PEROVSKITES}

956107 Investigation of degradation mechanisms of perovskite-based photovoltaic devices using laser beam induced current mapping [9561-8]

\section{SESSION $3 \quad$ MATERIALS AND PROCESSES}

956108 Robust measurement of thin-film photovoltaic modules exhibiting light-induced transients [9561-5]

956109 Sol-gel deposition and plasma treatment of intrinsic, aluminum-doped, and gallium-doped zinc oxide thin films as transparent conductive electrodes [9561-9]

\section{SESSION 4 LIGHT MANAGEMENT}

$9561 \mathrm{OE} \quad$ Light absorption enhancement in elliptical nanohole array for photovoltaic application [9561-14]

\section{POSTER SESSION}

9561 0J Simple one step spray process for CulnS 2 / $\ln _{2} S_{3}$ heterojunctions on flexible substrates for photovoltaic applications [9561-19]

$9561 \mathrm{OL}$ Characterization of $\mathrm{Cu}_{2} \mathrm{ZnSnS}_{4}$ thin films prepared by the sulfurization of co-sputtered metal precursors [9561-21] 
9561 OM Device characteristics of antenna-coupled metal-insulator-metal diodes (rectenna) using $\mathrm{Al}_{2} \mathrm{O}_{3}, \mathrm{TiO}_{2}$, and $\mathrm{Cr}_{2} \mathrm{O}_{3}$ as insulator layer for energy harvesting applications [9561-24]

$95610 \mathrm{~N}$ The electrodeposition of multilayers on a polymeric substrate in flexible organic photovoltaic solar cells [9561-25] 
Proc. of SPIE Vol. $9561956101-5$

Downloaded From: https://www.spiedigitallibrary.org/conference-proceedings-of-spie on 26 Apr 2023 Terms of Use: https://www.spiedigitallibrary.org/terms-of-use 


\title{
Authors
}

Numbers in the index correspond to the last two digits of the six-digit citation identifier (CID) article numbering system used in Proceedings of SPIE. The first four digits reflect the volume number. Base 36 numbering is employed for the last two digits and indicates the order of articles within the volume. Numbers start with 00, 01, 02, 03, 04, 05, 06, 07, 08, 09, 0A, 0B...0Z, followed by 10-1Z, 20-2Z, etc.

\author{
Abusnina, Mohamed, OL \\ Al-Jassim, Mowafak, OL \\ Anderson, Tom H., 02 \\ Balakrishnan, Kaushik, 09 \\ Benammar, Mohieddine A., 09 \\ Cunha, Idaulo Jose, ON \\ Deceglie, Michael G., 08 \\ Ellingson, Randy J., 07 \\ Falco, Charles M., 09 \\ Faryad, Muhammad, 02 \\ Guedes, Andre F. S., ON \\ Guedes, Vilmar P., ON \\ Gurbuz, Yasar, OM \\ Heben, Michael J., 07 \\ Inac, Mesut, OM \\ Islam, M. Saif, 03 \\ Karaagac, Hakan, 03 \\ Kartha, C. Sudha, OJ \\ Khanal, Rajendra R., 07 \\ Kumar, K. Rajeev, OJ \\ Kurtz, Sarah R., 08 \\ Lakhtakia, Akhlesh, 02 \\ Liyanage, Geethika K., 07 \\ Mackay, Tom G., 02 \\ MacQueen, Rowan W., ix \\ Mankowski, Trent, 09 \\ Mansuripur, Masud, 09 \\ Marion, Bill, 08 \\ Matin, Mohammad, OL \\ Moutinho, Helio, OL \\ Ozcan, Meric, OM \\ Pan, Yongdong, $\mathrm{OE}$ \\ Phillips, Adam B., 07 \\ Qin, Xuefei, OE \\ Schmidt, Timothy W., ix \\ Shafique, Atia, OM \\ Shikoh, Ali Sehpar, 09 \\ Silverman, Timothy J., 08 \\ Singh, Rajendra, 02 \\ Song, Zhaoning, 07 \\ Souza, Monica L., ON \\ Tartari, Simone, ON \\ Thomas, Titu, OJ \\ Tompkins, Brandon L., 07 \\ Touati, Farid, 09 \\ Vijayakumar, K. P., OJ \\ VJ, Logeeswaran, 03 \\ Watthage, Suneth C., 07 \\ Wu, Yonggang, OE
}

Xia, Zihuan, OE

Yengel, Emre, 03

Zhang, Zongyi, $\mathrm{OE}$

Zhou, Jian, $\mathrm{OE}$

Zhu, Zhaozhao, 09 


\section{Conference Committee}

Symposium Chair

Oleg V. Sulima, GE Global Research (United States)

Conference Chairs

Louay A. Eldada, Quanergy Systems, Inc. (United States)

Michael J. Heben, The University of Toledo (United States)

Conference Program Committee

Bulent Basol, EncoreSolar, Inc. (United States)

Howard M. Branz, National Renewable Energy Laboratory (United States)

Paola Delli Veneri, ENEA (Italy)

David S. Ginley, National Renewable Energy Laboratory (United States)

Ivan Gordon, IMEC (Belgium)

William N. Shafarman, University of Delaware (United States)

Ayodhya N. Tiwari, EMPA (Switzerland)

\section{Session Chairs}

1 Simulation, Modelling, Testing, and Metrology

Zhaoning Song, The University of Toledo (United States)

2 Perovskites

Carina Bronnbaver, iMEET (Germany)

3 Materials and Processes

Zhaoning Song, The University of Toledo (United States)

4 Light Management

Michael G. Deceglie, National Renewable Energy Laboratory (United States) 
Proc. of SPIE Vol. $9561956101-8$

Downloaded From: https://www.spiedigitallibrary.org/conference-proceedings-of-spie on 26 Apr 2023 Terms of Use: https://www.spiedigitallibrary.org/terms-of-use 